\title{
EFTERORD
}

\section{EN AFSLUTTENDE REFLEKSION VEDRØRENDE MARCEL MAUSS' SKRIFT OM BØNNEN}

\section{BJØRN THOMASSEN}

Dette særnummer af Tidsskriftet Antropologi handler om bønnen. Det handler om at bede. Hvordan vi beder, hvornår vi beder, med hvem vi beder, til hvem vi beder. Derfor leder særnummeret også helt naturligt tilbage til Marcel Mauss' forfatterskab. Det var nemlig Mauss, der i slutningen af 1800-tallet pegede på bønnen som et centralt omdrejningspunkt for de gryende socialvidenskaber. Og så alligevel ikke. Mauss valgte bønnen som sit tema i 1897, i en alder af 28, da han skulle skrive sin specialeafhandling (,these de doctorat"). Det skulle vise sig at blive et skæbnesvangert valg. Mauss startede ud med en ambitiøs plan. I et stort anlagt flerbindsværk ville han dække både bønnens historiske oprindelse og dens praksisformer i en lang række kulturområder fra Australien til Indien. Mauss kæmpede med projektet i over ti år uden på nogen måde at blive endog halvt færdig. Det eneste, han fik skrevet, var et udkast til en introduktion og til den første diskussion om bønnens oprindelse svarende til cirka en fjerdedel af det oprindelige projekt. Til sidst gav han op. I 1909, 12 år efter at have påbegyndt arbejdet, lod Mauss udkastet cirkulere som en privat udgivelse i en lukket kreds af venner og bekendte. Formentlig blev der trykt blot seks kopier. En egentlig publikation så teksten først i 1968 i forbindelse med udgivelsen af Mauss' Ouvres. Og først i 2003 blev teksten oversat og udgivet på engelsk på initiativ af W.S.F. Pickering og med et glimrende forord af selvsamme (Mauss 2008 ${ }^{1}$ ).

Det var heller ikke, fordi Mauss i mellemtiden fandt på et bedre tema til sin afhandling. Han fik ganske enkelt ikke afsluttet sin uddannelse.

Der er to grunde til, at denne personlige fiasko må undre. For det første var Mauss en af de mest brillante forskertalenter i sin generation. Hans senere skrifter, fx om gaven, er med rette at betegne som klassikere. For det andet var Mauss ideelt positioneret til at få sat sin akademiske karriere på skinner. Onklen Emile Durkheim havde nemlig udset ham til sin arvtager. Andre lovende tænkere i perioden såsom Arnold van Gennep havde svært ved at slå igennem i den akade- 
miske verden, fordi de af den ene eller anden grund blev marginaliseret og udstødt af Durkheim, der skulle sætte sig så tungt på socialvidenskaberne (Thomassen 2016). Med Mauss forholder det sig altså lige omvendt. Han var hovedpersonen i opbygningen af sociologi og antropologi i Frankrig (og grundlagde senere Institut for Etnologi i Paris i 1925 sammen med Lucien Levy Bruhl og Paul Rivet). En mere central placering inden for det akademiske landskab kunne man simpelthen ikke få på det tidspunkt, hverken i Frankrig eller noget som helst andet sted $i$ verden.

Set i bakspejlet kan man roligt sige, at det var synd og skam, at Mauss ikke fik færdiggjort sin afhandling, ikke bare fordi det lange mislykkede forløb kom til at præge Mauss negativt, men også fordi Mauss faktisk havde fat i noget vigtigt. Mauss anskuer bønnen som noget helt og aldeles fundamentalt. Han mere end antyder, at bønnen kan betragtes som en vigtig nøgle til studiet af religion. Som Mauss starter sit skrift: „Af alle religiøse fænomener er der meget få, der, selv når de blot betragtes udefra, giver et så umiddlebart og rigt udtryk af liv og kompleksitet som det fænomen, bønnen er“" (Mauss 2008:1). Bønnen er, som Mauss slår fast fra start, „et af det religiøses liv centrale fænomener“ (op.cit.21). Derfor undrer Mauss sig med god grund over manglen på systematiske studier af bønnen. Hvis Mauss havde færdiggjort sit ambitiøse projekt, ville studier af bønnen med stor sandsynlighed have etableret sig som et centralt genstandsfelt i det 20. århundredes antropologi. Men sådan skulle det altså ikke komme til at gå. Pickering kunne således i 2003 indlede sin introduktion til Mauss' tekst med i store træk at gentage, hvad Mauss havde skrevet hundrede år tidligere: „Det er bemærkelsesværdigt, at bønnen som et selvstændigt tema for forskning stort set ikke har været studeret af antropologer for slet ikke at tale om sociologer“ (Pickering 2008:1). Og dette er værd at understrege: Det er bønnen, af alle religiøse praksisser, der ikke finder plads i sociologien og antropologien i dens formative periode.

Jeg vil i dette korte efterord ikke gå videre ind i selve Mauss' tekst, ej heller diskutere bønnen som etnografisk fænomen - det gør artiklerne i dette særnummer hver især på så glimrende vis. Jeg vil i stedet pege på nogle af de omstændigheder, der kan være med til at forklare, hvorfor projektet skulle volde så mange kvaler for Mauss. Kort og godt: Hvordan kan det være, at Marcel Mauss aldrig kunne få færdiggjort sin afhandling om bønnen?

Selv om Mauss' skrift om bønnen i store træk forsvandt i den store glemmebog selv inden for religionssociologien, er spørgsmålet naturligvis blevet stillet af andre (se Bert 2020 for en nylig diskussion). En udbredt, men temmelig problematisk antagelse er, at forklaringen ligger i Mauss' personlighed og temperament, hans efter sigende mangel på beslutsomhed og systematik. Durkheim står således 
tilbage som den seriøse grundlægger af sociologien, Mauss som en talentfuld, men ,playful bohemian“ (Pickering 1998:43-44). Dette bekræftes på overfladen af de beskyldninger, som Durkheim kontinuerligt rettede mod sin nevø, nemlig at han sløsede sin ellers så lovende karriere væk.

Pickering gennemgår i sin introduktion til bogen om bønnen andre mulige årsager til Mauss' kvaler. Der er således ingen tvivl om, at Mauss løb ind i et velkendt problem: Andre antropologer blev ved med at komme ham i forkøbet. En stor del af hans datamateriale havde de australske klansamfund som omdrejningspunkt. Men Mauss havde ikke selv indsamlet de etnografiske data, og andre antropologer arbejdede i samme periode på det selvsamme materiale, blandt andet Spencer og Gillen og lingvisten og den lutherske missionær Carl Strehlow. I modsætning til Mauss havde Strehlow boet i Sydaustralien i flere år og havde lært sig selv tre af de indfødte sprog - en ekspertise og indsigt, som Mauss slet ikke kom i nærheden af (Stehlow var i øvrigt den første til at oversætte Det Nye Testamente til et af de indfødte sprog, dieri). Fordi de australske klansamfund i antropologiens begyndelse blev anset for at udgøre det mest ,primitive“ eller „elementære" slags samfund, man havde kilder på, udkom der omkring århundredeskiftet og ind i det 20. århundrede en lang række forsøg på at beskrive og fortolke deres religiøse riter og praksisformer, ofte i håbet om at etablere en teori om religionens dybere væsen og årsag. Mange andre store navne, deriblandt Arnold van Gennep, Sigmund Freud og naturligvis Durkheim selv, skulle i begyndelsen af det 20. århundrede kaste deres øjne på de australske klansamfund. Jo længere Mauss blev ved med at arbejde på materialet, desto større et problem havde han med strømmen af nye data fra andres feltarbejde og med nyhedsværdien. Derfor måtte Mauss kontinuerligt sætte spørgsmålstegn ved de foreløbige analyser og ved kvaliteten af de indkomne data. Ikke mindst kan man formode, at Mauss begyndte at betvivle den evolutionistiske præmis om klansamfundenes status som stående på det første ,udviklingstrin“, en præmis, som åbenlyst gennemsyrer Mauss' tilgang, og som er lige så tydelig i Durkheims senere værk om religionernes elementære former (Durkheim 1995 [1912]; se også diskussionen i Howard Morphys „Conluding Anthropological Reflections“ i Mauss 2008:149-50).

Men som Pickering selv noterer (Pickering 2008:4), skulle det dog være mærkeligt, om Mauss allerede inden århundredeskiftet valgte at droppe et så stort anlagt projekt, udelukkende fordi en tysk lingvist i samme periode skrev og publicerede om de australske klansamfund. Det kan ganske enkelt ikke være hele forklaringen. At Mauss blev ved med at anse bønnen som noget helt centralt for studiet af religion, kan der heller ikke sås tvivl om. Mauss designede og underviste i 1902 et kursus i bøn ved Ecole Pratique des Hautes Etudes, der bar titlen „En teori om bønnens elementære former (Australien, Melanesien)“ (se Fournier 2006:93). 
Pickering konkluderer derfor, at det må forblive et mysterium, hvorfor Mauss' projekt aldrig blev til noget, et mysterium, som Mauss tog med sig i graven. Men som Pickering også noterer, og som jeg i det følgende vil understrege yderligere, har hele affæren omkring denne ikke-udgivelse utvivlsomt at gøre med Mauss' komplicerede forhold til sin onkel, Emile Durkheim.

Når denne diskussion har interesse i dag, er det naturligvis ikke blot af biografiske årsager. For antropologer har familiesladder jo en værdi i sig selv, og værdien bliver ikke just mindre, når den omhandler grundlæggerne af vores disciplin. Men den latente konflikt mellem Mauss og Durkheim peger også ind i nogle centrale metodiske og teoretiske diskussioner, der i sidste ende handler om, hvilken slags disciplin antropologien kan og bør være. Her er det indledningsvis værd at bemærke, at Mauss var i fornemt selskab i forhold til fejlsslagne specialeafhandlinger. Hans student og gode ven, Robert Hertz (1881-1915), formåede nemlig heller ikke at færdiggøre sit speciale, som ironisk nok handlede om synd og forsoning. Pickering (2008:2) bemærker sammenfaldet, men gør intet ud af det. Det vil jeg vende tilbage til forneden, for i min læsning kan det hjælpe os til at opklare mysteriet.

\section{Marcel Mauss og Emile Durkheim: en kompliceret historie}

Mauss' adgang til det akademiske liv var på alle måder gået igennem Durkheim. Som 18-årig rejste Mauss til Bordeaux for at studere filosofi under Durkheim. Durkheim forblev indtil sin død i 1917 en omnipresent figur i Mauss' liv, både privat og arbejdsmæssigt. Durkheim var et slags familieoverhoved, en rolle, der blot blev bestyrket, efter Mauss mistede sin fader i 1898. Durkheim anså Mauss som sin nærmeste discipel, student og medarbejder. Durkheim kaldte endog Mauss for sit alter ego (Founier 2006:20).

Da Mauss i starten af 1890'erne flyttede til Paris for at færdiggøre sin uddannelse i religiøse studier, betød det på ingen måde en løsrivelse fra Durkheim, tværtimod. Durkheim havde på det tidspunkt identificeret religion som det genstandsfelt, omkring hvilket han ville opbygge sin sociologiske videnskab. At Mauss valgte at specialisere sig i religionsvidenskab, var helt i tråd med onklens ønske og behov. Durkheim blev ved med at følge Mauss' liv og arbejde ned til den mindste detalje, selv på geografisk afstand. Det kan man blandt andet se i de breve, Durkheim skrev til Mauss i perioden (gengivet i Durkheim 1998; Mauss' breve til Durkheim gik desværre tabt under Anden Verdenskrig).

Arbejdsrelationen til Durkheim blev om muligt endnu mere tæt fra 1898, hvor Durkheim grundlagde tidsskriftet L'Année Sociologique med Mauss som sin tætteste og vigtigste medarbejder. Og det er altså i samme periode, at Mauss vælger at skrive sin afhandling om bønnen. 
Valget faldt ikke i god jord hos Durkheim. Mauss sendte et først udkast af sit manuskript til Durkheim, som viste sig ekstremt kritisk over for hele projektet (Pickering 2008:2). Mauss var i samme periode sammen med sin ven Hubert gået i gang med et ambitiøst essay om offeret (Hubert \& Mauss 1898), et studie, som Durkheim anså for aldeles centralt for etableringen af religionssociologien. Durkheim var besat af ideen om offeret og offerritualer som et slags fundament for det sociale liv (en yderst problematisk antagelse, som Mauss senere blev klar over). Durkheim fulgte Hubert og Mauss tæt og intervenerede direkte i deres arbejde og insisterede på, at essayet skulle have ordet „funktion“ i titlen, som retteligt blev til „Et essay om offerets natur og funktion“ (se november/december 1998-brev fra Durkheim til Mauss i Durkheim 1998:181). I flere af de breve, som Durkheim skriver til Mauss i perioden, opfordrer Durkheim direkte Mauss til at prioritere arbejdet med Hubert og dernæst arbejdet med deres tidsskrift. Som Durkheim skriver i et brev fra januar 1898: „Jeg mener, at undersøgelsen [om offeret] er aldeles vigtig, og at du skal hellige dig fuldstændig til den. Din afhandling og alt det andet må vente“ (se Fournier 2006:70; se også 18. december-brev af Durkheim i Durkheim 1998:185).

I andre breve demotiverer Durkheim Mauss via en næsten nådesløs kritik. Mens han viser faderlig opmærksomhed, kritiserer han samtidig Mauss for ikke at besvare alle hans breve og for ikke at holde ham informeret om hvert eneste skridt i sit arbejde. En række breve skrevet af Durkheim fra 1900 er særligt afslørende om en voksende konflikt mellem de to (Durkheim 1998:241-50; se også vores diskussion i Szakolczai \& Thomassen 2019:71-73). Presset på Mauss er konstant, næsten dagligt. Durkheim beskylder Mauss for at „spilde sin tid“ med „uvigtige forhold“ og for ikke at udføre alle de opgaver, der er blevet ham pålagt. Durkheim instruerer løbende Mauss om, hvad han „bør“" gøre, forkaster hans egne ideer som „latterlige“ (8. januar-brev, Durkheim 1998:243), bebrejder ham for hans „ukvalificerede forsømmelighed“ og beskylder ham direkte for at lyve (udateret januarbrev, opcit.244). Durkheim blander vrede, desillusion og selvmedlidenhed: „Jeg vil ikke spilde min tid på at fortælle dig, hvor ked af det jeg er på dine vegne, for det vil alligevel ikke røre dig" starter et andet brev (ibid.), der slutter med ordene „Jeg er ked af din ufølsomhed“ og et PS: „Uret tikker.“ At beskylde Mauss for ikke at være i stand til at afslutte sin afhandling og samtidig insistere på, at han skal prioritere arbejdet med ofring og de mange opgaver forbundet med deres tidsskrift, kan af gode grunde ses som et næsten arketypisk eksempel på et batesonsk double bind. 


\section{Robert Hertz: Mauss' åndsfælle og skæbnepartner}

At Mauss' problem med specialet i høj grad kan tilskrives det til stadighed mere komplekse forhold til hans berømte onkel, bekræftes af et andet forhold: nemlig at Robert Hertz (1881-1915), en anden af Durkheims elever og nærmeste medarbejdere, heller ikke formåede at færdiggøre sin afhandling. Det er vigtigt at huske på, at alt dette foregår inden for den afgørende periode, hvor Durkheim bevidst prøver at etablere et både metodisk, teoretisk og institutionelt grundlag for sociologien og antropologien. Durkheims programmatiske bog om selvmordet udkom i 1897 (og det var i øvrigt også i dette tilfælde Mauss, der i Paris havde skaffet Durkheim det statistiske materiale via Gabriel Tarde), men derefter kaster Durkheim i høj grad sit blik på religionen.

Hertz' talent var ubestrideligt, og det var tydeligt for alle omkring ham. Hertz var syv år yngre end Mauss og blev fra starten af sine studier hans elev. Mauss så op til ham fra det øjeblik, de mødte hinanden, og opfattede ham snarere som en ligeværdig samtalepartner („Han var allerede en mester blandt mestrene“(Mauss om Hertz)). Kort efter sin aggregation i filosofi i 1904 begyndte Hertz arbejdet på sin specialeafhandling, ligeledes under Durkheims supervision. Akkurat som Mauss blev han heller aldrig færdig. Hertz' speciale bar titlen „Synd og ekspiation i primitive samfund“ („Le péché et l'expiation dans les sociétés primitives“). Ligesom Mauss blev Hertz fra 1905 inddraget af Durkheim til at forestå det store og vigtige arbejde med tidsskriftet Année Sociologique. Mauss og Hertz blev nære venner og fandt $i$ hinanden en gensidig inspiration. Formelt set var dette helt, som det skulle være, for sammen med Hubert udgjorde Mauss og Hertz indercirklen i den durkheimske skole. Men det er kun en del af historien.

Det var Mauss, der tog initiativ til at få Hertz' ufærdige arbejde udgivet i 1922, og han skrev selv både forord og efterord til udgivelsen. Mauss stod i dyb gæld til Hertz. Mauss understreger, hvordan det ufærdige speciale var skrevet „En smule under indflydelse af Durkheim, men først og fremmest ved hjælp af den rette ånd, logikken, og dyb meditation“ (Mauss i Hertz 1922:16). Durkheim er da også kun nævnt (men ikke diskuteret) en enkelt gang i Hertz' speciale. Og da Hertz for alvor tager hul på diskussionen om syndens væsen, er det ikke Durkheim, han går i dialog med, men derimod Nietzsche (op.cit.22). En mere bandlyst forfatter inden for den durkheimske skole finder man nok ikke. I efterskriftet til Hertz' ufærdige tekst (Mauss i op.cit.55-59) citerer Mauss med dyb respekt en række af Hertz' efterladte noter, som Mauss kalder for en veritabel „skat“, et „eksempel“, som videre generationer bør bygge videre på. Mauss' undervisning ved Collège de France i årene 1932-37 er eksplicit dedikeret til Hertz' arbejde, som Mauss tydeligvis ønsker at videreføre - ikke bare substantielt, men 
også i den ,ånd““, som Hertz for Mauss var det ypperste eksempel på (se Mauss' noter til undervisningsplanen i op.cit.60-64).

Mauss var udmærket klar over Nietzsche betydning for Hertz, for de havde læst og diskuteret Nietzsche igennem mange år. Fra starten af deres venskab læste Mauss og Hertz sammen de ,forbudte“ figurer, der lå uden for fransk positivisme og tysk neokantianisme, blandt andet Bergson og Péguy. I det stille og uden nogen som helst form for åben konfrontation bevægede de sig væk fra Durkheim i søgen efter nye ideer (Riley \& Besnard 2002:5). En af de figurer var Nietzsche.

Som Alexander Riley (1999) påviser, læste Mauss, Hertz og andre studerende omkring dem Nietzsche i flere intensive perioder. Nietzsches værk om moralitetens genealogi, som Hertz diskuterer i sit speciale, forblev et centralt tema i korrespondancen mellem Mauss og Hertz i løbet af krigen, en korrespondance, der fortsatte helt op til Hertz' ulykkelige død i et slag under Første Verdenskrig den 13. april 1915. Kort forinden skriver Hertz i et brev fra fronten til sin kone Alice (januar 1915): „I mine drømme om fremtiden ser jeg et Europa frigjort fra den 'deutsche Professor' [Kant], som var vores forfærdelige arketype“ (Riley 1999:192); en arketype, der i Frankrig blev formidlet af ingen ringere end Durkheim.

Det er og forbliver et fortolkningsspørgsmål, men det forekommer mig, at den mest overbevisende forklaring på Mauss' og Hertz' mislykkede afhandlinger er: De vidste, at deres afhandling ikke kunne undslippe Durkheims ,opmærksomme øjne"; derfor måtte de forsøge at efterleve hans og omverdenens forventninger, men dette var ikke kompatibelt med deres intellektuelle integritet. Derfor måtte de lade deres projekter forblive ufuldstændige, alt imens de fandt på alle mulige undskyldninger undervejs.

\section{Tilbage til den religiøse praksis}

Lad mig her være eksplicit, hvad angår en ofte problematisk reception af Mauss' værk. Mauss er naturligvis alment anerkendt som en afgørende figur i antropologien, ,antropologiens fader", men han placeres alt for ofte som en mellemfigur mellem Durkheim og Lévi-Strauss, altså som en medierende figur i et triumvirat, der sammen definerer den „franske antropologiske skole“. Mauss „videreførte“ den durkheimske skole, som det så ofte siges, og var samtidig "forløber" for strukturalismen. Denne standardberetning om Durkheim-Mauss-Lévi-Strausstrilogien indkapsler fejlagtigt Mauss' værker i funktionalisme og strukturalisme, en afkodning, der ganske enkelt forhindrer et reelt engagement i Mauss' arbejde og dets teoretiske potentiale (Thomassen 2012a). Som vi har argumenteret (Szakolczai \& Thomassen 2019), kan man snarere læse Mauss som en dyb og 
refleksiv selvkritiker, der forsøger at arbejde sig ud af onklens skygge, samtidig med at han også efter Durkheims død bliver set som hovedmanden bag den durkheimske skole. I flere af Mauss' senere værker, fx essayet om „personen“, fortsætter dobbeltspillet: Mauss starter et essay med at identificere den durkheimske skoles position i forhold til det givne genstandsfelt, som han tilsyneladende vil applicere, men snarere end at bekræfte de durkheimske metodiske principper skriver han sig stille og roligt ud af dem.

Når man læser Marcel Mauss' skrift om bønnen, kan man næsten ikke lade være med at stille et spørgsmål, som på overfladen kan virke irrelevant: Bad han selv? Det er velkendt, at Marcel Mauss omkring 18-årsalderen holdt op med at være praktiserende jøde til sin moders store fortrydelse. Men Mauss' skrift om bønnen indeholder alligevel en „forstående“ tilgang. Mauss” tilgang til religion er på ingen måde subjektiv - han giver ingen direkte eksempler taget fra sit eget liv, og hele sproget er præget af et eksplicit ønske om nøgtern videnskabelighed. Det er ikke på nogen måde et teologisk skrift. Mauss vil definere sit objekt, så det kan studeres komparativt. Sproget er teknisk og objektivt. Men samtidig er Mauss' tilgang ikke religiøst umusikalsk.

For Mauss er bønnen en praksis: I bønnen både „,handler og tænker den troende“, som Mauss skriver (2008:22). Og allerede her fornemmer man, hvor svært forenelig bønnen er med Durkheims eksternalitetsprincip (nemlig Durkheims berømte diktum, at det sociale faktum består af måder at handle tænke og føle på, som ligger uden for individet). Naturligvis har bønnen en både kropslig og psykologisk dimension. Selv når en bøn forekommer som en ren mekanisk gentagelse, „så er den stadig et udtryk for et minimum of religiøse ideer og følelser" (Mauss 2008:22). Nogle mennesker beder aldrig. Nogle gør det dagligt og helt systematisk. Nogle gør det i specifikke situationer eller på specifikke tider på året. Og så er der mennesker, der beder, når de rammes af en sindsstemning, som når de fyldes med afmagt og sorg eller dybfølt taknemmelighed over verdens skønhed. Mauss forfølger ikke denne psykologiske dimension, men han forkaster den heller ikke. Og netop denne psykologiske dimension, som Durkheim så radikalt ønskede at adskille fra sociologien, er, hvad Mauss meget senere indoptager i sit habitusbegreb som en del af „kroppens teknikker“. Det skal ikke glemmes, at Mauss giver den mest præcise definition af habitusbegrebet i en forelæsning for det franske selskab for psykologer i 1934. Og for Mauss handler habitus ikke om en durkheimsk „,kollektiv bevidsthed“, der udøver „tvang“ over individet, men snarere om en praktisk roeson, som samtidig er at placere på det kollektive og det individuelle niveau (Mauss 1973; Mauss' mest radikale og åbne opgør med Durkheims kollektivisme kom til udtryk i hans skrift om bolsjevismen og den russiske revolution; se diskussion i Thomassen 2012b). 
Mauss' ufærdige værk om bønnen kan på den vis ses som det første skridt i bevægelsen væk fra den selvsamme durkheimske skole, som han på ironisk og skæbnesvanger vis blev udnævnt som repræsentant for - og det stadigvæk i dag. Men det er et tøvende skridt, og Mauss tør ikke tage det fuldt ud. Men så kan vi andre jo gå planken ud. Ved hjælp af den rette ånd, logikken, og dyb meditation.

\section{Note}

1. Alle citater fra Mauss' værk om bønnen er fra anden udgave af den engelske oversættelse. Oversættelser til dansk er min egne.

\section{Litteratur}

Bert, Jean-François

2020 Priez, priez, il en restera toujours quelque chose. Revue des sciences sociales 64: 164-71.

Durkheim, Emile

1995 The Elementary Forms of Religious Life. New York: Free Press.

1998 Lettres à Marcel Mauss. Introduced and annotated by P. Besnard and M. Fournier. Paris: PUF.

Fournier, Marcel

2006 Marcel Mauss. A Biography. Princeton: Princeton University Press.

Hubert, Henri \& Marcel M. Mauss

1964 [1898] Sacrifice. Its Nature and Function. Foreword by E.E. Evans-Pritchard.

Chicago \& London: The University of Chicago Press.

Hertz, Robert

1922 Le péché et l'expiation dans les sociétés primitives. Revue de l'histoire des religions, Annales du Musée Guimet. Paris: Ernest Leroux.

Mauss, Marcel

1973) [1935] Techniques of the Body. Economy and Society 2(1):70-88. https://doi.org/10.1080/ 03085147300000003.

1992 [1924-25] A Sociological Assessment of the Bolshevism. In: M. Gane (ed.): The Radical Sociology of Durkheim and Mauss. London: Routledge.

Pickering, William

1998 Mauss's Jewish Background. In: W. James \& N.J. Allen (ed.): Marcel Mauss. A Centuary Tribute. New York: Berghahn.

2008 Introduction to an Unfinished Work. In: M. Mauss. On Prayer. Pp. 1-15. New York: Berghahn.

Riley, Alexander T.

1999 Whence Durkheim's Nietzschean Grandchildren? A Closer Look at Robert Hertz's Place in the Durkheimian Genealogy. Archives Européennes de Sociologie 40(2): 304-30. https://doi.org/10.1017/S0003975600007499. 
Riley, Alexander T. \& Philippe Besnard (eds)

2002 Un ethnologue dans les tranchées. Lettres de Robert Hertz à sa femme Alice (août 1914-avril 1915). Paris: CNRS.

Szakolczai, Arpad \& Bjørn Thomassen

2019 From Anthropology to Social Theory. Rethinking the Social Sciences.

Cambridge: Cambridge University Press.

Thomassen, Bjørn

2012a Durkheim between Gabriel Tarde and Arnold van Gennep. Founding Moments of Sociology and Anthropology. Social Anthropology 20(3):231-49. https://doi.org/ 10.1111/j.1469-8676.2012.00204.x.

$2012 \mathrm{~b} \quad$ Notes towards an Anthropology of Political Revolutions. Comparative Studies of Society and History 54(3):679-706. https://doi.org/10.1017/S0010417512000278.

2016 The Hidden Battle that Shaped the History of Sociology. Arnold van Gennep Contra Emile Durkheim. Journal of Classical Sociology 16(2):173-95. https://doi.org/10.1177/1468795X15624191. 